\title{
Adenomatoid odontogenic tumor: Case report
}

\author{
Tumor odontogênico adenomatoide: Relato de caso \\ Tumor odontogénico adenomatoide: Reporte de caso
}

Received: 03/16/2021 | Reviewed: 03/22/2021 | Accept: 03/23/2021 | Published: 04/02/2021

\author{
Karolina Braga Costa \\ ORCID: https://orcid.org/0000-0001-8351-6456 \\ Federal University of Mato Grosso do Sul, Brazil \\ E-mail: karolinabraga_@hotmail.com \\ Alana Oswaldina Gavioli Meira dos Santos \\ ORCID: https://orcid.org/0000-0002-5591-5262 \\ Federal University of Mato Grosso do Sul, Brazil \\ E-mail: nagavioli@gmail.com \\ Muryllo Eduardo Sales dos Santos \\ ORCID: https://orcid.org/0000-0001-8517-4154 \\ University of Mato Grosso do Sul, Brazil \\ E-mail: muryllosales@gmail.com \\ Carla Beatriz Fernandes de Oliveira \\ ORCID: https://orcid.org/0000-0002-7052-0066 \\ Federal University of Mato Grosso do Sul, Brazil \\ E-mail: carlabeatriz18@hotmail.com \\ Thabata Flavia Ribeiro Guimaraes da Silva \\ ORCID: https://orcid.org/0000-0002-6547-8836 \\ Federal University of Mato Grosso do Sul, Brazil \\ E-mail: thabata.guimaraes@ufms.br \\ Maisa de Oliveira Aguillera \\ ORCID: https://orcid.org/0000-0003-0055-6984 \\ Federal University of Mato Grosso do Sul, Brazil \\ E-mail: maisa.aguillera@live.com \\ Julio Cesar Leite da Silva \\ ORCID: https://orcid.org/0000-0002-9835-7432 \\ University of Mato Grosso do Sul, Brazil \\ E-mail: julio.silva@ufms.br \\ Daniella Moraes Antunes \\ ORCID: https://orcid.org/0000-0002-7557-5461 \\ University of Mato Grosso do Sul, Brazil \\ E-mail: dani07antunes@gmail.com \\ Ellen Cristina Gaetti-Jardim \\ ORCID: https://orcid.org/0000-0003-2471-465X \\ University of Mato Grosso do Sul, Brazil \\ E-mail: ellen.jardim@ufms.br
}

\begin{abstract}
The adenomatoid odontogenic tumor is a benign epithelial pathology that comprises 3 to $7 \%$ of odontogenic tumors. It has the characteristic of slow and progressive growth and almost no symptoms, being more frequent in women especially in the first two decades of life. Also, the anterior region of the maxilla is the anatomical location mostly affected. A white female patient, 16 years old, presented absence of the canine, first, and second maxillary premolars on the right side, prolonged retention of the right upper deciduous second molar, volumetric increase in the buccal and palatal alveolar ridge with extension to the bottom of the right maxillary vestibule, being diagnosed after the incisional biopsy as an adenomatoid odontogenic tumor. Considering the clinical and radiographic examination, it was decided to perform decompression of the lesion before performing enucleation and curettage.
\end{abstract}

Keywords: Odontogenic tumors; Diagnosis differential; Conservative treatment.

\section{Resumo}

O tumor odontogênico adenomatóide é uma patologia epitelial benigna que compreende de 3 a $7 \%$ dos tumores odontogênicos. Tem a característica de crescimento lento e progressivo e quase sem sintomas, sendo mais frequente em mulheres principalmente nas duas primeiras décadas de vida. Além disso, a região anterior da maxila é a localização anatômica mais afetada. Paciente feminina, branca, 16 anos, apresentava ausência dos caninos, primeiro e segundo pré-molares superiores do lado direito, retenção prolongada do segundo molar superior decíduo direito, aumento volumétrico na crista alveolar vestibular e palatina com extensão para baixo do vestíbulo maxilar direito, 
sendo diagnosticado após a biópsia incisional como tumor odontogênico adenomatóide. Considerando o exame clínico e radiográfico, optou-se pela descompressão da lesão antes da realização da enucleação e curetagem.

Palavras-chave: Tumores odontogênicos; Diagnóstico diferencial; Tratamento conservador.

\section{Resumen}

El tumor odontogénico adenomatoide es una patología epitelial benigna que comprende del 3 al $7 \%$ de los tumores odontogénicos. Tiene la característica de crecimiento lento y progresivo y casi sin síntomas, siendo más frecuente en mujeres especialmente en las dos primeras décadas de vida. Además, la región anterior del maxilar es la localización anatómica más afectada. Paciente mujer de raza blanca, 16 años, que presentó ausencia de canino, primer y segundo premolares superiores del lado derecho, retención prolongada del segundo molar deciduo superior derecho, aumento volumétrico del reborde alveolar bucal y palatino con extensión hacia abajo. del vestíbulo maxilar derecho, siendo diagnosticado tras la biopsia incisional como un tumor odontogénico adenomatoide. Teniendo en cuenta el examen clínico y radiográfico, se decidió realizar la descompresión de la lesión antes de realizar la enucleación y legrado.

Palabras clave: Tumores odontogénicos; Diagnóstico diferencial; Tratamiento conservador.

\section{Introduction}

The adenomatoid odontogenic tumor is a benign epithelial pathology that comprises 3 to $7 \%$ of odontogenic tumors. It was considered a variant of ameloblastoma called "odontoameloblastoma" or "ameloblastic adenomatoid tumor" until 1948 when Stafne published it as a distinct entity (Stafne, 1948; Neville et al., 2004; Manohar et al., 2020).

It has the characteristic of slow and progressive growth and almost no symptoms, being more frequent in women especially in the first two decades of life. Also, the anterior region of the maxilla is the anatomical location mostly affected (Neville et al., 2004; Leon et al., 2005; Avelar et al., 2008; Roza et al., 2020).

Regarding the radiographic characteristics, it is presented with a delimited unilocular radiolucent aspect and is usually associated with an unerupted tooth (Louredo et al., 2017; Dwivedi et al., 2019; Câmara et al., 2016). Most AOTs does not exceed $3 \mathrm{~cm}$ in their largest diameter, although it is possible a presentation with greater extent (Mohamed et al., 2010).

From the histopathological point of view, this odontogenic tumor is involved in a fibrous capsule, with a solid central region or with cystic alterations. It has spindle-shaped epithelial cells that form a cord that is similar to rosettes around a central space that may be empty or with eosinophilic material. Another characteristic of this lesion is scarce or even absent ducts that consist of a space circumscribed by a layer of epithelial or cubic cells (Neville et al., 2004).

The adenomatoid odontogenic tumor is classified into two types: peripheral and intraosseous. The peripheral has as differential diagnosis an epulis connected to the labial gingiva. The intraosseous type is subdivided into follicular that involves an impacted tooth (almost always diagnosed as a dentigerous cyst) and the extrafollicular which is the opposite of the follicular one and is often diagnosed as a root residue or periodontal cyst (Philipsen e Reichart, 1999).

The histopathological presentation helps to choose the most conservative therapy. Its treatment consists of removing the lesion through curettage or enucleation without major difficulties because it has a fibrous capsule that stands out easily (Philipsen e Reichart, 1999). Thus, the objective of this paper is to present a case of a patient that occurred in the city of Campo Grande, Mato Grosso do Sul, diagnosed as an adenomatoid odontogenic tumor, as well as the surgical technique used and its prognosis.

\section{Methodology}

In order to do this observational study, a signed consent for treatment, image use, and scientific exposure was obtained from the patient. Furthermore, all ethical procedures considering a case report were respected.

\section{Case Report}

A white female patient, 16 years old, attended the Clinic Complex of the School of Dentistry of the Federal University 
of Mato Grosso do Sul, Brazil (FAODO - UFMS) looking for dental care. The patient reported that she had "teeth that did not appear yet and a swelling in the same region for approximately 4 months".

During anamnesis, it was reported that the patient did not have any systemic comorbidity and noted the delay in "teeth appearing in the mouth" about 4 months ago. She denied pain complaints, referring only to aesthetic complaints when smiling.

The extraoral physical examination showed no alterations. The oroscopy showed absence of the canine, first, and second maxillary premolars on the right side, prolonged retention of the right upper deciduous second molar, volumetric increase in the buccal and palatal alveolar ridge with extension to the bottom of the right maxillary vestibule. Upon palpation, the region was dense, painless, with normal temperature and coloration.

In the panoramic radiography examination, a radiolucent lesion was observed, well delimited in the region of the right maxilla, with approximately $2 \mathrm{~cm}$ in its largest diameter, presence of the canine, first and second upper premolars inside of the lesion.

Considering the clinical and radiographic examination, the differential diagnoses were: dentigerous cyst, adenomatoid odontogenic tumor, and odontogenic myxoma. Thus, it was decided to perform an incisional biopsy for diagnosis.

An intraosseous incisional biopsy was performed under local anesthesia and, simultaneously, a device for decompression of the lesion was installed. The device placed aimed to provide decompression of the lesion, due to the transoperative characteristics suggesting an odontogenic lesion (Figure 1).

Figure 1 - Clinical and radiographic aspects of the adenomatoid odontogenic tumor. (A) Panoramic radiographic examination showing the presence of a radiolucent lesion, well delimited in the region of the right maxilla, with approximately $2 \mathrm{~cm}$ in its largest diameter and the presence of the canine, first, and second premolars inside of the lesion. (B) Preoperative appearance highlighting the presence of a volumetric increase in the vestibular and palatal alveolar ridge with extension to the bottom of the right maxillary vestibule. (C) Surgical access to perform the incisional biopsy. (D) Installation of a device for decompression of the lesion.

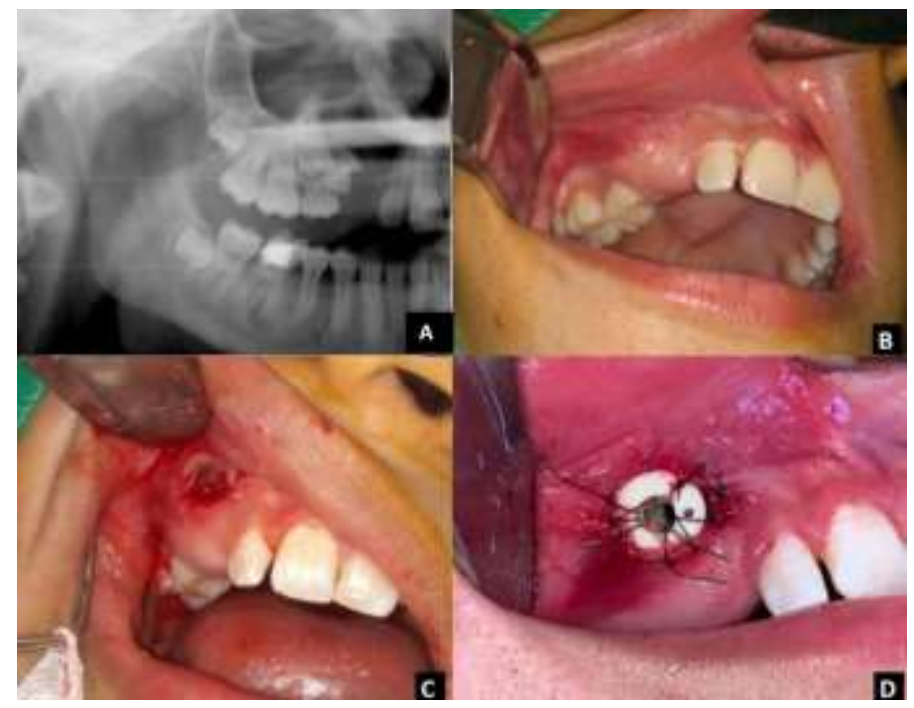

Source: Authors.

In the histopathological analysis, the piece showed multiple fragments of soft tissue, with an irregular shape, brownish color, friable and fibrous consistency. Also, multiple fragments of hard tissue, brownish color, and hardened consistency. Microscopically, the histological sections revealed a fragment of an odontogenic lesion characterized by scarce cell strands, nests, and ductiform structures formed by epithelial cells, sometimes cubic, sometimes cylindrical. Eosinophilic and 
amorphous material, as well as areas of calcification, were observed in the middle of the epithelial arrangement. The stroma of the lesion comprised most of the specimen and was composed of fibrous connective tissue and areas of bone neoformation with irregular trabeculae. Hemorrhage areas complete the histological picture. Thus confirming the diagnosis of Adenomatoid Odontogenic Tumor (Figure 2).

Figure 2 - Histological aspects. The figure below shows the histopathological characteristics of the studied lesion. (A) Dystrophic calcification areas amid epithelial proliferation. Hematoxylin-eosin (HE), 200x. (B) Fusiform epithelial cell nests in fibrous connective tissue stroma. HE, 200x. (C) Ductiform spaces of varying sizes, lined by a single layer of cubic cells. HE, 200x.

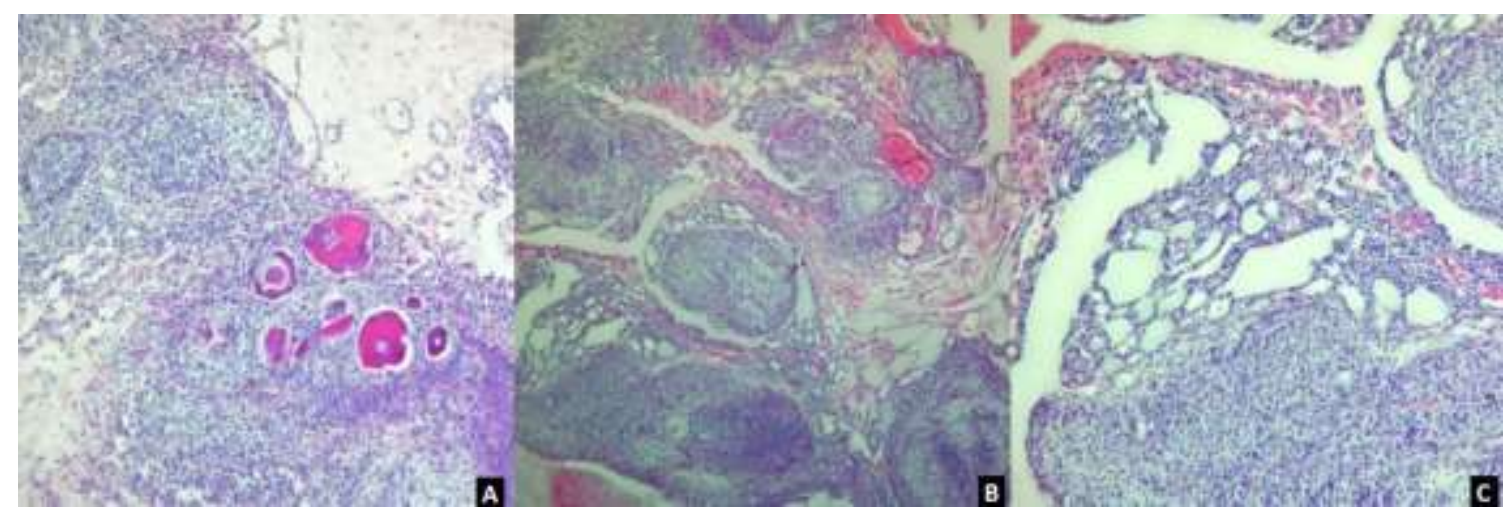

Source: Authors.

In the 7-day postoperative follow-up, no signs of infection were observed. The vestibular volumetric increase in the right maxilla was in regression, the second right upper deciduous molar presented mobility, and the beginning of the eruption of the first upper premolar on the right side could be seen. The decompression device was removed and the patient was instructed to perform oral hygiene and irrigation of the fistula with $0.9 \%$ saline solution.

Considering the clinical improvement with regression of the lesion and the beginning of the eruption of the impacted tooth, a new surgery for enucleation associated with curettage was performed to preserve the impacted teeth.

In a 3-month follow-up, the patient had no complaints. Intra-oral regression of volumetric increase in the right maxilla and partial tooth eruption were observed ${ }^{14}$. Radiographic examination showed regression of the lesion and new bone formation in the right maxilla. The patient was referred for orthodontic treatment and is still on clinical and radiographic follow-up (Figure $3)$. 
Figure 3 - Radiographic aspects after 3 months of conservative surgical treatment. Local bone neoformation and impacted tooth displacement.

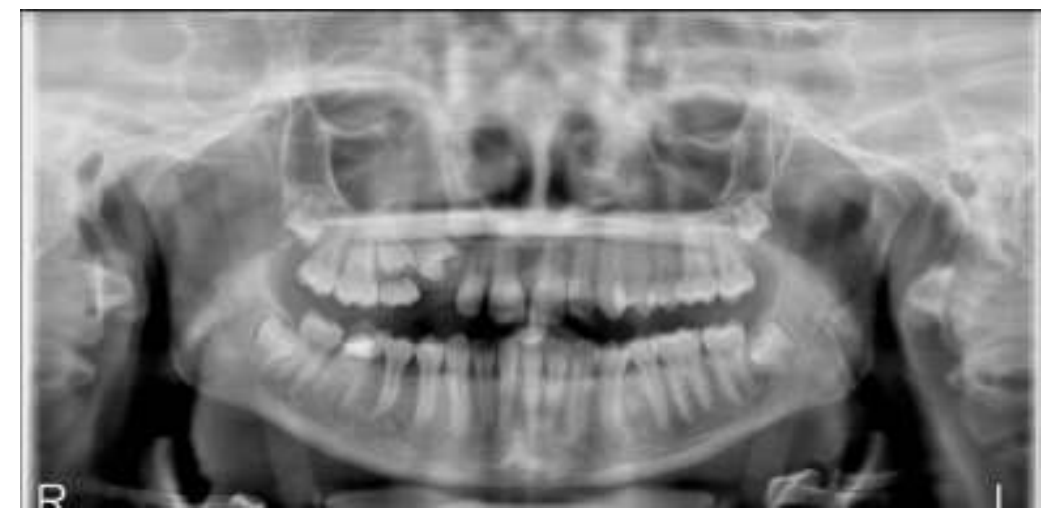

Source: Authors.

\section{Discussion}

The adenomatoid odontogenic tumor is one of the lesions commonly mentioned in epidemiological studies on odontogenic tumors (Aregbesola et al., 2018; Ahire et al., 2018; Nalabolu et al., 2017). A retrospective study by Philipsen shows that the intraosseous follicular clinical variant that is reported in this case, represents $70.8 \%$ of the cases of AOT (Philipsen et al., 2007).

This pathology is also called a "two-thirds tumor" because two-thirds occur in young women, two-thirds of the cases involve the maxilla, two-thirds are related to unerupted teeth and two-thirds occur with canines. Usually, the teeth involved are impacted and the adjacent teeth may be slightly dislocated (Katiyar et al., 2019). All of these findings were present in the report in question, in addition to the involvement of the upper premolars on the right side.

Enucleation and curettage is the most common treatment modality for AOT (Vasudevan et al., 2012). This type of neoplasia does not need extensive surgery because it has characteristics of benignity. It is usually a well-defined lesion, since the capsule is not so adhered to the surrounding bone and the recurrence rate is low (Neville et al., 2004; Erdur et al., 2016).

The histogenesis of AOT is still uncertain; there is a question as to whether it represents anomalous hamartomatous growth or a true benign neoplasm (Shaikh et al., 2018). In 2005, WHO defined the histological type of the adenomatoid odontogenic tumor describing it as a tumor composed of the odontogenic epithelium with a variety of histological patterns within a stroma of connective tissue (Castillejos et al., 2015). Histopathological examination for diagnosis is essential since AOT presents clinical similarities with other oral lesions of more common occurrence.

Due to the characteristics of the lesion, the patient's age, space for the eruption of the teeth, and low recurrence rate of adenomatoid odontogenic tumors, decompression was performed, followed by enucleation and curettage. As a result, in the follow-up consultations we observed the regression of the lesion, new bone formation in the periphery as well as irruptive movements of the impacted teeth.

\section{Conclusion}

Even though the treatment of choice for Adenomatoid Odontogenic Tumor is surgical excision associated with curettage, and it presents a good prognosis without incidences of recurrence, in the case presented, the incisional biopsy and decompression procedure using a device was a good option of treatment before enucleation and curettage, once it reduced the size of the tumor enabling a less aggressive treatment.

It is important to note that this is a unique clinical case, with its scientific limitations. Thus, more work must be done 
to increase statistical reliability.

\section{References}

Ahire, M. S., Tupkari J. V., Chettiankandy, T. J., Thakur, A., \& Agrawal, R. R. (2018). Odontogenic tumors: A 35 -year retrospective study of 250 cases in an Indian (Maharashtra) teaching institute. Indian Journal of Cancer, 55(3), 265-72.

Aregbesola, B., Soyele, O, Effiom, O., Gbotolorun, O., Taiwo, O., \& Amole, I. (2018). Odontogenic tumours in Nigeria: A multicentre study of 582 cases and review of the literature. Medicina Oral, Patologia Oral, Cirugia Bucal, 23(6), 61-766.

Avelar, R. L., Antunes, A. Z., Santos, T. S., Andrade, E. S. S., \& Dourado, E. (2008). Tumores odontogênicos: estudo clínico-patológico de 238 casos. Revista Brasileira de Otorrinolaringologia, 74, 668-73.

Câmara, P. R., Dutra, S. N., Carmo, A. B. C., Takahama Júnior, A., \& Azevedo, R. S. (2016). Tumor odontogênico adenomatoide: relato de um caso clínico destacando os seus principais diagnósticos diferenciais. Revista Brasileira de Odontologia, 73(4), 348-52.

Castillejos, R. D., Munguía, A. M. N., \& Ham, G. C. Adenomatoid odontogenic tumor. (2015). Case report and literature review. Revista Odontológica Mexicana, 19(3), 183-7.

Dwivedi, D., Prabhakar, N., Kasetty, S. et al. (2019). Peripheral adenomatoid odontogenic tumor in a cloak of an epulis: report of a rare case. BMC Oral Health, 19, 81 .

Erdur, E. A., Ileri, Z., Ugurluoglu, C., Cakir, M., \& Dolanmaz, D. (2016). Eruption of an impacted canine in an adenomatid odontogenic tumor treated with combined orthodontic and surgical therapy. American Journal of Orthodontics and Dentofacial Orthopedics, 149(6), 923-7.

Katiyar, A., Gupta, S., Gupta, K., \& Pandey, M. (2019). Trauma to Tumor: A Hunt of Adenomatoid Odontogenic Tumor-A Rare Case Report. International Journal of Clinical Pediatric Dentistry, 12(4), 366-369.

Leon, J. E., Mata, G., M., Fregnani, E., R., Carlos-Bregni, R., de Almeida, O. P., Mosqueda-Taylor, A., \& Vargas, P. A. (2005). Clinicopathological and immunohistochemical study of 39 cases of Adenomatoid Odontogenic Tumour: a multicentric study. Oral Oncology, 41(8), 835-42.

Louredo, B. V. R., Freitas, C. T. S., Camara, J., \& Liborio-Kimura, T. N. (2017). Estudo epidemiológico de lesões odontogênicas provenientes do Departamento de Patologia e Medicina Legal da Universidade Federal do Amazonas. Revista Brasileira de Odontologia, 74(2), 126-132.

Manohar, B., Verma, N., Mannan, N., \& Bhuvaneshwari, S. (2020). Adenomatoid odontogenic tumor mimicking a lateral periodontal cyst - A rare case report in the mandible. J Indian Soc Periodontol, 24(5):473-476.

Mohamed, A., Singh, A. S., Raubenheimer, E. J., \& Bouckaert, M. M. (2010). Adenomatoid odontogenic tumour: review of the literature and an analysis of 33 cases from South Africa. International Journal of Oral and Maxillofacial Surgery, 39(9), 843-6.

Nalabolu, G. R. K., Mohiddin, A., Hiremath, S. K. S., Manyam, R., Bharath, T. S., \& Raju, P. R. (2017). Epidemiological study of odontogenic tumours: An institutional experience. Journal of Infection and Public Health, 10(3), 324-30.

Neville, B. W., Allen, C. M., Damm, D. D., et al. (2004). Patologia: Oral \& Maxilofacial. Guanabara Koogan.

Philipsen, H. P., Reichart, P. A., Siar, C. H., Ng, K. H., Lau, S. H., Zhang, X, et al. (2007). An updated clinical and epidemiological profile of the adenomatoid odontogenic tumour: a collaborative retrospective study. Journal of Oral Pathology \& Medicine, 36(7), $383-93$.

Philipsen, H. P., \& Reichart, P. A. (1999). Adenomatoid odontogenic tumour: facts and figures. Oral Oncology, 35(2), 125-31.

Roza, A. L. O. C., Carlos, R., van Heerden, W. F. P., de Andrade, B. A. B., Mosqueda-Taylor, A., Santos-Silva, A. R., Lopes, M. A., de Almeida, O. P., Romañach, M. J., \& Vargas, P. A. (2020). An international collaborative study of 105 new cases of adenomatoid odontogenic tumors. Oral Surg Oral Med Oral Pathol Oral Radiol, 9:S2212-4403(20)31033-6.

Shaikh, S., Bansal, S., Desai, R. S., \& Ahmad, I. (2018). Aggressive adenomatoid odontogenic tumor of the mandible: A rare case report and review of the literature. Journal of Oral and Maxillofacial Pathology, 22(1), 11-5.

Stafne, E. C. (1948). Epithelial tumors associated with developmental cysts of the maxilla; a report of three cases. Oral Surgery Oral Medicine Oral Pathology, 1(10), 887-94.

Vasudevan, K., Kumar, S., \& Vijayasamundeeswari, V. S. (2012). Adenomatoid odontogenic tumor, an uncommon tumor. Contemporary Clinical Dentistry, $3(2), 245-247$. 